\title{
Center, periphery, shadow. The geopolitical pattern after Euro-, Schengencrisis and Brexit
}

\author{
Georg Vobruba (vobruba@uni-leipzig.de) \\ University of Leipzig, Germany
}

Extraordinary problems are the European Unions' ordinary modus operandi. This is common knowledge. But does it apply even if problems pile up? What is the impact of the crisis of the common currency, the crisis of the Schengen area of free personal movement plus the aftermath of the Brexit vote in Great Britain? Will this accumulation of crises trigger further steps of integration? Or will it turn out as the beginning of the end of the EU? Or will something in between emerge? And if so: what?

In the following I shall offer a sketch, how current crises are likely to reshape the geopolitical structure of the EU.

I. The European Union is based on a specific geopolitical structure, composed of mutual relations of all single EU-members. Programmatically, from its beginning EU integration operated by marching in step, hence consisting of equally integrated members. In practice at all times graded integration was the standard pattern, encompassing different levels of integration, different living standards, and power differentials.

II. Already previous to the invention of the Euro it was clear that introducing the common currency in the EU is a "highly complex experiment" (Padoa-Schioppa 1994: 163), hence the Eurocrisis its logical consequence. Thus, not its mere occurrence but its severity was a surprise. Indeed, the Eurocrisis turned out to be a fundamental challenge for the EU. At present (end of 2016) the Eurocrisis is not solved but over. This means: Due to the crisis several new institutions are built, but it is unclear whether they are able to master the problems related with the common currency enduringly or simply postpone a big crash. In other words: The Eurocrisis has triggered relevant supplementary institution building (Banking union, ESM), but it is not sure whether this will be enough.

III. Since summer 2015 people fleeing life-threatening situations and economic despair in their home countries triggered a crisis of the Schengen arrangement. The Schengencrisis is a fundamental challenge of the European border regime, so far consisting of free movement within the Schengen area and strict controls of its outer borders. This balance between inner freedom and outer control collapsed due to the number of refugees, desperately trying to reach the affluent center of the EU, causing several attempts to reestablish border controls within the Schengen area and triggering severe conflicts between the center and the periphery of the EU. Until today the EU is lost in a triangle between national egoisms, humanitarian demands and fragile political arrangements with authoritarian neighbor states in order to withhold refugees. The Schengencrisis is pending and overlapping the Eurocrisis..

IV. For such a constellation, more than 100 years ago famous Swiss historian Jacob Burckhardt (1905/2005) coined the term "Krisenkreuzung" - crossing of crises. Does it mean that things deteriorate; that two crises mean double trouble? Not necessarily, as one has to take into account that some effects of both crises might neutralize each other. Just to mention one obvious effect: Because the Schengencrisis absorbs almost all political attentiveness, the political management of the Eurocrisis has be- 
come much less hysterical. One crisis (Euro) becomes overshadowed by the other (Schengen). This was the effect, Burckhardt basically had in mind. But mutual neutralizing effects might go far beyond that (Vobruba 2017: 91ff.)).

V. Both the Euro- and the Schengencrisis affect the relationship between the center and the periphery of the EU. In order to make this clear it is useful to understand this constellation as a political exchange relationship. The periphery commits itself to political and economic modernization and to operating as a buffer in order to absorb several kinds of border crossing problems coming from outside. The center in return offers administrative and financial support, (selective) freedom of personal movement, and - in the long term - participation in its wealth. This was the more or less hidden deal of the Eastern enlargement and analogous of the European neighborhood policy.

VI. The exchange relationship between the center and the periphery remained intact until the worldwide financial crisis after 2007. The Eurocrisis unveiled a strong dependency of the periphery on the center. Whilst in the beginning of the crisis in 2007 there was a kind of a mutual dependency between center and periphery, in the course of the crisis the EU-center was able to get rid of it. Thus dependency became one sided at the expense of crisis ridden Southern EU-members, in particular Greece. They can't but accept financial aid from the center, thus forced to become exposed to transformative pressure which in some respect (Vobruba 2017: 77ff.) resembles former socialist countries transformation and its social costs.

VII. The Schengencrisis in contrast manifests that the center depends on the periphery. Thanks to the treaty of Schengen, a new border constellation emerged: they are both national borders and the EUs outer border (Bach 2010). This double coding induces two effects. On the one hand for periphery members it means abandoning (or sharing) an important part of national sovereignty. On the other hand the center abdicates controlling the influx in the common Schengen area, hence their national territory. This arrangement collapsed with the big flight peaking in 2015. Now it turned out that without the periphery members' willingness and ability to control the common EU-border, the refugee problem turns into a distributional problem several EUmembers apparently are unwilling or unable to solve.

VIII. Both crises resulted in a breakdown of hitherto functioning political exchange arrangements. Thus the management of both crises aims at re-fixing political exchange arrangements at new terms. The Eurocrisis leads to a higher level of integration of the center and to austerity measures, covertly threatening the periphery to be excluded from the Euro-zone or even from the EU. The Schengencrisis reveals the centers' need to dispose of a buffer zone, hence guaranteeing the peripheries' membership in the EU. As far as the geopolitical structure of the EU is concerned, the impact of Eurocrisis and the Schengencrisis tend to neutralize each other. But this is just two third of the story.

IX. As the Schengencrisis got on, political disputes became more and more concentrated on conflicts and bargains between the center, some southern members and some neighbors of the EU. In a shadow zone of these conflicts between the center and the periphery unfolds a development, creating a sort of "third countries": EU-members, hardly affected by the Eurocrisis and anxious to stay away from any EU attempts to solve the Schengencrisis commonly. This might change the geopolitical pattern of the EU as we know it fundamentally. This is where Hungary, Poland in the East and Great Britain in the West come into play. What can be expected? Any answer can't be but speculative. I use a sociological and a political argument.

X. First sociologically: In his seminal work "Soziologie" Georg Simmel (1908/1992) analyzes "conflict" as a modus of social integration in contrast to mutual indifference. For conflicts are normal in modern society, society building by conflict must be seen as the normal case. Of course not all kinds of conflict contribute to society building, the crucial point is, whether they take place within a given frame. Simmel points to common values as such a frame, institutions antagonists can't question and damage 
might play an analogous role (Vobruba 2012).

XI. Second politically: Whilst the center and the (southern) periphery of the EU is involved in intense conflicts about how to share the cost of the Euro- and the Schengencrisis, middle eastern EU-member countries and Great Britain successfully managed to keep away from such conflicts. And what is more, some EU-members try to suspend institutional rules, which so far provided a common frame for conflict and compromise. With respect to Eastern this is a step by step development, with respect to Great Britain it happens as a big bang, the Brexit. Whatever its final result: In the perspective of Simmel this clearly indicates one step out of an emerging European society.

XII. Euro- and Schengencrisis will leave a graded integrated as well as a divided EU: On the one side one can expect complex political exchange relationships between the center and the southern periphery evolve, all in all resulting in a geopolitical structure of graded integration. On the other side we will find some poorly integrated EUmembers and halfhearted connected neighbors somewhere in the shadow.

References

Bach, Maurizio 2010. Die Konstitution von Räumen und Grenzbildung in Europa. Von verhandlungsresistenten und verhandlungsabhängigen Grenzen. In: Monika Eigmüller, Steffen Mau (Hg.), Gesellschaftstheorie und Europapolitik. Wiesbaden: Springer VS.

Burkhardt, Jakob 1905/2005. Weltgeschichtliche Betrachtungen. Stuttgart: Kröner.

Padoa-Schioppa, Tommaso 1994. The Road to Monetary Union in Europe. Oxford: Clarendon Press.

Simmel, Georg 1908/1992. Soziologie. Frankfurt a, M.: Suhrkamp.

Vobruba, Georg 2012. The Social Construction of the European Society. In: Harry F. Dahms, Lawrence Haselrigg (eds.), Theorizing Modern Society as a Dynamic Process. Bingley: Emerald. Pp. 263-279.

Vobruba, Georg 2017. Krisendiskurs. Die nächste Zukunft Europas. Weinheim, Basel: Beltz Juventa. 